\title{
The Analysis of Running Distances in National Teams in 2010 and 2014 FIFA World Cup and Estimation of Oxygen Consumption Capacity Based on These Distances
}

\author{
İrfan Marangoz \\ Correspondence: İrfan Marangoz, Ahi Evran University, School of Physical Education and Sports, Kırşehir, Turkey.
}

Received: April 17, 2018

Accepted: June 4, $2018 \quad$ Online Published: June 19, 2018

doi:10.11114/jets.v6i8.3213

URL: https://doi.org/10.11114/jets.v6i8.3213

\begin{abstract}
This study aims to analyze running distances in national teams during 2010 and 2014 FIFA World Cup and to propose a new program which estimates oxygen consumption capacity based on running distances. The data were evaluated by SPSS 22.0 statistical package program. The findings demonstrate that among teams participating in 2010 and 2014 FIFA World Cup, the lowest average running distance and estimated $\mathrm{VO}_{2} \max$ values belong to Brazil with 7398.77 meters and $43.84 \mathrm{ml} / \mathrm{kg} / \mathrm{m}$, respectively. On the other hand, the highest average running distance and estimated $\mathrm{VO}_{2} \mathrm{max}$ values belong to Australia with 10598 meters and $67.69 \mathrm{ml} / \mathrm{kg} / \mathrm{m}$, respectively. The average running distance and estimated $\mathrm{VO}_{2}$ max value in national teams participating in 2010 FIFA World Cup was 9635.54 meters and 60.52 $\mathrm{ml} / \mathrm{kg} / \mathrm{m}$, while they were 9095.82 meters and $52 \mathrm{ml} / \mathrm{kg} / \mathrm{m}$ in 2014 FIFA World Cup, respectively.
\end{abstract}

Keywords: FIFA World Cup 2010-2014, running distances, $\mathrm{VO}_{2}$ max

\section{Introduction}

Historical developments and natural conditions (pitch conditions, cultural values and physical features) lead to the emergence of different playing styles in different regions and countries of the world. There are different schools in various countries of the world, and each school brings a new taste to football. For instance, English football attaches importance to running, physical tackling, long passes and a high tempo until the end of 90 minutes. Brazilian football seems to have reached the highest elegance on the pitch. On the other hand, German and Dutch football is based on a more detailed technical game plan, and requires long running distances (Wahl, 2005).

The energy spent during a football game requires players to possess some physiological capacities, which are directly associated with player's physical condition and training methods. Football requires different approaches depending on the playing style, position on the pitch and difficulty level of the match. All players need to possess the ball during the game, and become fast and active in order to support their teammates for defensing and attacking. They are often expected to run for 90 minutes and support the teammate possessing the ball in a suitable position on the pitch (Reilly, 2003).

\section{Methods}

The average running distances during the tournament were used to estimate running distance in these national teams. (M-0.3138)/0.0.278 formula, which was developed by Cooper (Cooper, 1968) was used to estimate approximate VO2max values of the teams. The numbers in this formula (1), which enables to estimate VO2max values during 12 minutes, were multiplied by 3 in order to estimate VO2max values for 36 minutes. In a football match, during a half of 45 minutes, nearly 9 minutes are spent passively (penalty kick, free kick, goal kick, fouls etc.). Thanks to our modified formula, a new VO2max formula was developed in order to approximately estimate running distances in a football match. As a result, oxygen consumption of the players in a team was estimated based on their running distances.

$$
\mathrm{VO}_{2} \max =\text { Running Distance-0.9414/0.0834 }
$$

[Running Distance/1 mile (1.609m)]

Direct $\mathrm{VO}_{2} \max$ estimation may pose threats to a player's life because it needs to be measured on his respiratory, circulatory and heart system. In fact, it is compulsory to maintain a medical staff during a $\mathrm{VO}_{2}$ max measurement. Nevertheless, as mentioned above, methods for $\mathrm{VO}_{2} \max$ measurement have not been developed yet. These estimations usually yield results similar to direct $\mathrm{VO}_{2} \max$ measurements. However, these methods are called "sub-maximal 
measurements" because circulatory and respiratory systems are not fully activated.

\section{$2.1 \mathrm{VO}_{2} \max$ Test}

The average running distances during the tournament were used to estimate running distance in these national teams. (M-0.3138)/0.0.278 formula, which was developed by Cooper (Cooper, 1968).

Direct VO2max estimation may pose threats to a player's life because it needs to be measured on his respiratory, circulatory and heart system. In fact, it is compulsory to maintain a medical staff during a VO2max measurement. Nevertheless, as mentioned above, methods for VO2max measurement have not been developed yet. These estimations usually yield results similar to direct VO2max measurements. However, these methods are called "sub-maximal measurements" because circulatory and respiratory systems are not fully activated.

\subsection{Statistical Analyses}

After the data were analyzed through the SPSS 22 software program, descriptives statictics analysis was used to the analysis of running distances in national teams in 2010 and 2014 FIFA World Cup and estimation of oxygen consumption capacity based on these distances.

\section{Findings}

Table 1. Average running distances and $\mathrm{VO}_{2}$ max values in national teams participating in 2010 and 2014 FIFA World Cup

\begin{tabular}{|c|c|c|c|c|c|}
\hline \multirow[b]{2}{*}{ Teams } & \multirow[t]{2}{*}{$\mathbf{N}$} & \multicolumn{2}{|r|}{2010} & \multicolumn{2}{|r|}{2014} \\
\hline & & $\begin{array}{c}\text { Distance } \\
(\mathbf{m})\end{array}$ & $\begin{array}{c}\mathrm{VO}_{2} \\
(\mathrm{ml} / \mathrm{kg} / \mathrm{min})\end{array}$ & $\begin{array}{c}\text { Distance } \\
(\mathbf{m})\end{array}$ & $\begin{array}{c}\mathrm{VO}_{2} \\
(\mathrm{ml} / \mathrm{kg} / \mathrm{min})\end{array}$ \\
\hline Australia & 2 & 10598 & 67.69 & 9775.3 & 61.56 \\
\hline Swiss & 2 & 10342 & 65.78 & 9349.8 & 58.39 \\
\hline Portugal & 2 & 10160 & 64.43 & 9103.3 & 56.55 \\
\hline Mexica & 2 & 10093.75 & 63.93 & 9213.75 & 57.37 \\
\hline Germany & 2 & 10061.86 & 63.69 & 9855.66 & 62.16 \\
\hline Serbia & 1 & 10014 & 63.34 & - & - \\
\hline South Africa & 1 & 9957.333 & 62.92 & - & - \\
\hline America & 2 & \begin{tabular}{|l|}
9946.18 \\
\end{tabular} & 62.83 & 9996 & 63.20 \\
\hline Italy & 2 & 9926 & 62.68 & 8924.6 & 55.22 \\
\hline Japan & 2 & 9887.06 & 62.39 & 9143 & 56.85 \\
\hline South Korea & 2 & 9860.5 & 62.19 & 9404.6 & 58.80 \\
\hline Britain & 2 & 9856.75 & 62.17 & 9076 & 56.35 \\
\hline Slovakia & 1 & 9755.75 & 61.41 & - & - \\
\hline North Korea & 1 & \begin{tabular}{|l|}
9753.667 \\
\end{tabular} & 61.40 & - & - \\
\hline Slovenia & 1 & \begin{tabular}{|l|}
9707.667 \\
\end{tabular} & 61.05 & - & - \\
\hline Uruguay & 2 & 9636.15 & 60.52 & 8848.25 & 54.65 \\
\hline Chile & 2 & 9559.25 & 59.95 & 9439.7 & 59.06 \\
\hline Spain & 2 & 9531.65 & 59.74 & 9212 & 57.36 \\
\hline Algeria & 2 & 9519.667 & 59.65 & 9385,2 & 58.65 \\
\hline Denmark & 1 & 9496.667 & 59.48 & - & - \\
\hline Paraguay & 1 & 9483.11 & 59.38 & - & - \\
\hline Greece & 2 & 9423.333 & 58.94 & 8462.1 & 51.77 \\
\hline Netherlands & 2 & 9411.73 & 58.85 & 9360,96 & 58.47 \\
\hline France & 2 & 9366.667 & 58.51 & 9091,8 & 56.47 \\
\hline New Zealand & 1 & 9333 & 58.26 & - & - \\
\hline Cameroon & 2 & 9321.333 & 58.18 & 8476.3 & 51.88 \\
\hline Ivory & 2 & 9283.667 & 57.89 & 8271.6 & $50 \mathrm{cc35}$ \\
\hline Ghana & 2 & 9268.37 & 57.78 & 9408.3 & 58 ç82 \\
\hline Brazil & 2 & 9107 & 56.58 & 7398.77 & $43 c ̧ 85$ \\
\hline Honduras & 2 & 9092 & 56.47 & 8117.3 & $49 \mathrm{c} 20$ \\
\hline Argentina & 2 & 8976.4 & 55.61 & 8818.64 & 54.43 \\
\hline Nigeria & 2 & 8606.667 & 52.85 & 8862.5 & 54.76 \\
\hline Costa Rica & 1 & - & - & 8920.3 & 55.19 \\
\hline Belgium & 1 & - & - & 9205.2 & 57.31 \\
\hline Colombia & 1 & - & - & 8851.6 & 54.68 \\
\hline Croatia & 1 & - & - & 9097.3 & 56.51 \\
\hline Equator & 1 & - & - & 8929.6 & 55.26 \\
\hline Iran & 1 & - & - & 9497.6 & 59.49 \\
\hline Bosnia & 1 & - & - & 9526 & 59.70 \\
\hline Russia & 1 & - & - & 10043.3 & 63.56 \\
\hline Team averages and $\mathrm{VO}_{2}$ max values & & 9635.54 & 60.52 & 9095.82 & 56.50 \\
\hline
\end{tabular}

\footnotetext{
* The lowest running distance among national teams participating in 2010 and 2014 FIFA World Cup (Brazil)
}

** The highest running distance among national teams participating in 2010 and 2014 FIFA World Cup (Australia) 
Average Running Distances in National Teams Participating in 2010 FIFA World Cup 9635.54 meters.

Average Running Distances in National Teams Participating in 2014 FIFA World Cup 9095.82 meters

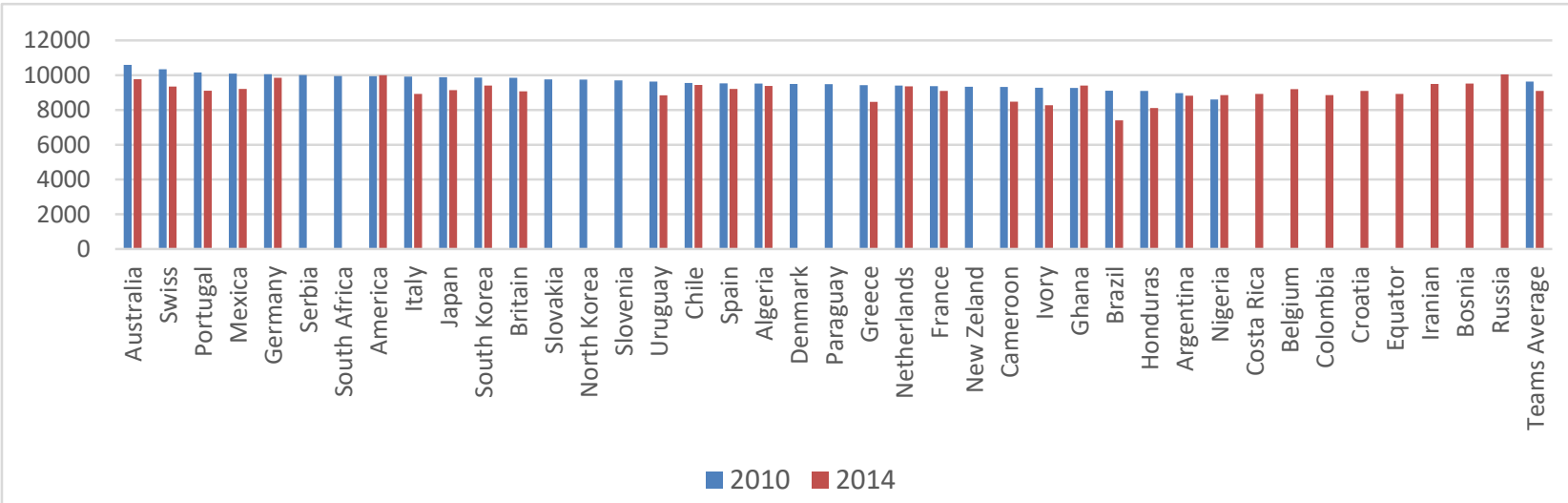

Graph 1. Average Running Distances in National Teams Participating in 2010 and 2014 FIFA World Cup

Table 2. Average running distances in national teams participating in 2010 and 2014 FIFA World Cup and standard deviation of their success

\begin{tabular}{|c|c|c|c|c|c|c|c|}
\hline Row & Teams & $\mathbf{N}$ & $\begin{array}{c}2010 \text { Average } \\
\text { Running Distance }\end{array}$ & 2010 Success & $\begin{array}{c}2014 \text { Average } \\
\text { Running Distance }\end{array}$ & 2014 Success & $\begin{array}{c}2010-2014 \\
\text { X } \pm \text { sd }\end{array}$ \\
\hline 1 & Spain & 2 & 9531,65 & Winner & 9212 & Group Stage & $9371,83 \pm 226,03$ \\
\hline 2 & Netherlands & 2 & 9411,73 & Runner-up & 9360,96 & Third Place & $9386,35 \pm 35,90$ \\
\hline 3 & Germany & 2 & 10061,86 & Third Place & 9855,66 & Winner & $9958,76 \pm 145,81$ \\
\hline 4 & Uruguay & 2 & 9636,15 & Fourth Place & 8848,25 & Round of 16 & $9242,20 \pm 557,13$ \\
\hline 5 & Argentina & 2 & 8976,4 & Quarter Final & 8818,64 & Runner-up & $8897,52 \pm 111,55$ \\
\hline 6 & Ghana & 2 & 9268,37 & Quarter Final & 9408,3 & Group Stage & $9338,34 \pm 98,95$ \\
\hline 7 & Paraguay & 1 & 9483,11 & Quarter Final & - & - & 9483,11 \\
\hline 8 & Brazil & 2 & 9107 & Quarter Final & 7398,77 & Fourth Place & $8252,89 \pm 1207,90$ \\
\hline 9 & America & 2 & 9946,18 & Round of 16 & 9996 & Round of 16 & $9971,09 \pm 35,23$ \\
\hline 10 & Japan & 2 & 9887,06 & Round of 16 & 9143 & Group Stage & $9515,03 \pm 526,13$ \\
\hline 11 & South Korea & 2 & 9860,5 & Round of 16 & 9404,6 & Group Stage & $9632,55 \pm 322,37$ \\
\hline 12 & Mexica & 2 & 10093,75 & Round of 16 & 9213,75 & Round of 16 & $9653,75 \pm 622,25$ \\
\hline 13 & Chile & 2 & 9559,25 & Round of 16 & 9439,7 & Round of 16 & $9499,48 \pm 84,53$ \\
\hline 14 & Slovakia & 1 & 9755,75 & Round of 16 & - & - & 9755,75 \\
\hline 15 & Portugal & 2 & 10160 & Round of 16 & 9103,3 & Group Stage & $9631,65 \pm 747,20$ \\
\hline 16 & Britain & 2 & 9856,75 & Round of 16 & 9076 & Group Stage & $9466,38 \pm 552,07$ \\
\hline 17 & France & 2 & 9366,667 & \begin{tabular}{|l} 
Group Stage \\
\end{tabular} & 9091,8 & Quarter Final & $9229,23 \pm 194,36$ \\
\hline 18 & South Africa & 1 & 9957,333 & Group Stage & - & - & 9957,33 \\
\hline 19 & Nigeria & 2 & 8606,667 & Group Stage & 8862,5 & Round of 16 & $8734,58 \pm 180,90$ \\
\hline 20 & Greece & 2 & 9423,333 & Group Stage & 8462,1 & Round of 16 & $8942,72 \pm 679,69$ \\
\hline 21 & Slovenia & 1 & 9707,667 & Group Stage & - & - & 9707,67 \\
\hline 22 & Algeria & 2 & 9519,667 & Group Stage & 9385,2 & Round of 16 & $9452,43 \pm 95,08$ \\
\hline 23 & Australia & 2 & 10598 & Group Stage & 9775,3 & Group Stage & $10186,65 \pm 581,74$ \\
\hline 24 & Serbia & 1 & 10014 & Group Stage & - & - & 10014,00 \\
\hline 25 & Denmark & 1 & 9496,667 & Group Stage & - & - & 9496,67 \\
\hline 26 & Cameroon & 2 & 9321,333 & Group Stage & 8476,3 & Group Stage & $8898,82 \pm 597,53$ \\
\hline 27 & Italy & 2 & 9926 & Group Stage & 8924,6 & Group Stage & $9425,30 \pm 708,10$ \\
\hline 28 & New Zealand & 1 & 9333 & Group Stage & - & 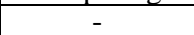 & 9333,00 \\
\hline 29 & Ivory & 2 & 9283,667 & Group Stage & 8271,6 & Group Stage & $8777,63 \pm 715,64$ \\
\hline 30 & North Korea & 1 & 9753,667 & Group Stage & - & - & 9753,67 \\
\hline 31 & Honduras & 2 & 9092 & \begin{tabular}{|l} 
Group Stage \\
\end{tabular} & 8117,3 & Group Stage & $8604,65 \pm 689,22$ \\
\hline 32 & Swiss & 2 & 10342 & Group Stage & 9349,8 & Round of 16 & $9845,90 \pm 701,59$ \\
\hline 33 & Costa Rica & 1 & - & & 8920,3 & Quarter Final & 8920,30 \\
\hline 34 & Belgium & 1 & - & & 9205,2 & Quarter Final & 9205,20 \\
\hline 35 & Colombia & 1 & - & & 8851,6 & Quarter Final & 8851,60 \\
\hline 36 & Croatia & 1 & - & & 9097,3 & Group Stage & 9097,30 \\
\hline 37 & Equator & 1 & - & & 8929,6 & Group Stage & 8929,60 \\
\hline 38 & Iran & 1 & - & & 9497,6 & Group Stage & 9497,60 \\
\hline 39 & Bosnia & 1 & - & & 9526 & Group Stage & 9526,00 \\
\hline 40 & Russia & 1 & - & & 10043,3 & Group Stage & 10043,30 \\
\hline
\end{tabular}


Table 3. Minimal and maximal running distances in national teams participating in 2010 and 2014 FIFA World Cup

\begin{tabular}{|c|c|c|c|c|c|}
\hline \multirow{2}{*}{$\begin{array}{l}\text { Teams } \\
\text { Australia } \\
\end{array}$} & \multicolumn{3}{|c|}{ NMinimumMaximum } & \multicolumn{2}{|c|}{$\mathrm{x} \pm \mathrm{sd}$} \\
\hline & 2 & 9775,30 & 10598,00 & 10186,65 & 581,7 \\
\hline & 11 & 10043,30 & 10043,30 & 10043,30 & \\
\hline Serbia & 1 & 10014,00 & 10014,00 & 10014,00 & \\
\hline America & & 9946,18 & 9996,00 & 9971,09 & 35,2 \\
\hline Jermany & 2 & 985 & 10061,86 & & 145,81 \\
\hline South Africa & 1 & 9957,33 & & 9957,33 & \\
\hline Swiss & 2 & 9349,80 & 10342,00 & 9845,90 & 701,5 \\
\hline Slovakia & 1 & 9755,75 & 9755,75 & 9755,75 & \\
\hline Korea & & 9753,67 & & 9753,67 & \\
\hline Slov & 1 & & & 67 & \\
\hline Mex & 2 & & 10 & 3,75 & 622,25 \\
\hline South Korea & 2 & 94 &, 50 & 9632,55 & 322,37 \\
\hline ort & 2 & 910 & 0,00 & 1,65 & 747,20 \\
\hline Bo & & & & & \\
\hline $\mathrm{Jan}$ & 2 & & & 03 & 526,13 \\
\hline hile & 2 & & &, 48 & 84,53 \\
\hline Iran & & 94 & 60 & 9497,60 & \\
\hline Denr & & 67 & & 67 & \\
\hline & & & & & \\
\hline n & & & & 38 & 552,07 \\
\hline $\lg 6$ & & & 67 &, 43 & 95,08 \\
\hline al & & & & 30 & 708,10 \\
\hline is & 2 & & & 35 & 35,90 \\
\hline in & & & & 83 & 226,03 \\
\hline Ghana & & & & 3,34 & 98,95 \\
\hline New Zealand & & & 00 & 00 & \\
\hline & & & & 20 & 557,13 \\
\hline ran & & & & 9,23 & 194,36 \\
\hline Belgium & & & & 5,20 & \\
\hline Croatia & & & & 9097,30 & \\
\hline Gree & & 84 & 33 & 8942,72 & 679,69 \\
\hline & & & &, 60 & \\
\hline Cost & & & & 30 & \\
\hline Cameroon & & & & 8898,82 & 597,53 \\
\hline Arge & & 8818,64 & 8976,40 & 8897,52 & 111,55 \\
\hline & & & & & \\
\hline & & & & 8777,63 & 715,64 \\
\hline Nigeria & & & 8862,50 & 8734,58 & 180,90 \\
\hline Hondur & & 811 & 9092,00 & 8604,65 & 689,22 \\
\hline Brazil & & 7398,77 & 9107,00 & 8252,89 & 1207,9 \\
\hline
\end{tabular}

\section{Discussion}

It can be observed that a player's running distance has increased in the last ten years. For instance, average running distance is nearly 11.000 meters in 90 minutes. Because players playing in different positions on the pitch perform different duties, midfielders', defenders' and forwards' running distances are estimated to be 11.4, 10.1 and 10.5 kilometers, respectively. It can be stated that a player's running distance during a football match varies between 8 and 11 kilometers. A football player performs different activities during a match such as standing (17.01\%), walking (40.4\%), low tempo running (35.1\%), high tempo running (8.1\%), high tempo sprint (0.7), as well as other activities such as tackling, headers and shooting, dribbling, and jumping (Günay, \& Yüce, 1996). The close proximity of football players with an average $\mathrm{MaxVO}_{2}$ values of $55-65 \mathrm{ml} / \mathrm{kg} / \mathrm{min}$ to long distance runners underlines the importance of the aerobic energy spent by these players (Marangoz, \& Gençay, 2017).

When $\mathrm{VO}_{2}$ max measurements of football teams are analyzed, Yamaner (1987) reports that $\mathrm{VO}_{2}$ max of 15 players in Gençlerbirliği was measured as $54.58 \mathrm{ml} / \mathrm{kg} / \mathrm{min}$. İşlegen (1987) stated that $\mathrm{VO}_{2}$ max value of 19 players in Turkish First Football League, 12 players in Turkish Second Football League and 18 players in Turkish Third Football League as $51.55 \mathrm{ml} / \mathrm{kg} / \mathrm{min}, 51.17 \mathrm{ml} / \mathrm{kg} / \mathrm{min}$ and $48.09 \mathrm{ml} / \mathrm{kg} / \mathrm{min}$, respectively. Yamaner (1990) found out that $\mathrm{VO}_{2}$ max value of 17 players in Galatasaray was $59.35 \mathrm{ml} / \mathrm{kg} / \mathrm{min}$. Müniroğlu et al. (2000) reports that $\mathrm{VO}_{2} \max$ value of 20 players in Turkish First Football League was measured as $59.48 \mathrm{ml} / \mathrm{kg} / \mathrm{min}$. Koç et al. (2000) observed that $\mathrm{VO}_{2} \mathrm{max}$ value of 18 players in Kütahyaspor, a football team in Turkish Third Football League, was $54.71 \mathrm{ml} / \mathrm{kg} / \mathrm{min}$. In a study on 63 football players in Turkish First, Second and Third Football League, Kizilet et al. (2002) measured $\mathrm{VO}_{2} \mathrm{max}$ as 54.34 
$\mathrm{ml} / \mathrm{kg} / \mathrm{min}$. Sinırkavak et al. (2004) reports that $\mathrm{VO}_{2} \max$ value of 10 players in Sivasspor was calculated as 42.84 $\mathrm{ml} / \mathrm{kg} / \mathrm{min}$. Marangoz \& Gençay (2017) demonstrated that $\mathrm{VO}_{2} \max$ values of two groups of 24 players in Kahramanmaraşspor and Siirtspor were measured as $57.62 \pm 3.25 \mathrm{ml} / \mathrm{kg} / \mathrm{min}$ and $59.45 \pm 4.46 \mathrm{ml} / \mathrm{kg} / \mathrm{min}$, respectively.

Reeves et al. (1999) measured $\mathrm{VO}_{2}$ max values of 18 players in English Premier League and 14 players in Hong Kong as $50.0 \mathrm{ml} / \mathrm{kg} / \mathrm{min}$ and $59.1 \mathrm{ml} / \mathrm{kg} / \mathrm{min}$, respectively. Ostojic (2000) reports that $\mathrm{VO}_{2}$ max values of two groups of 16 players in Serbian First and Third Football League was measured as $53.5 \mathrm{ml} / \mathrm{kg} / \mathrm{min}$ and $42.9 \mathrm{ml} / \mathrm{kg} / \mathrm{min}$, respectively. Edwards et al. (2003) found out that $\mathrm{VO}_{2}$ max value of 20 players in English Premier League was $62.1 \mathrm{ml} / \mathrm{kg} / \mathrm{min}$. In a study on 20 elite football players in Irish League, Mclntyre (2005) observed that $\mathrm{VO}_{2}$ max was calculated as 57.6 $\mathrm{ml} / \mathrm{kg} / \mathrm{min}$. In a study on 72 footbal players in Japan, Tahara et al. (2006) reported $\mathrm{VO}_{2}$ max as $54.0 \mathrm{ml} / \mathrm{kg} / \mathrm{dk}$.

Although the highest $\mathrm{VO}_{2}$ max value measured in studies on football players is $80 \mathrm{ml} / \mathrm{kg} / \mathrm{min}$, this value is nearly $55-68$ $\mathrm{ml} / \mathrm{kg} / \mathrm{min}$ for male football players except goalkeepers. It can be observed that $\mathrm{VO}_{2}$ max values measured in recent years have varied between 61.1 and $70.7 \mathrm{ml} / \mathrm{kg} / \mathrm{min}$ in recent years (Aşç1, 2003).

\section{Conclusion}

In conclusion, the modified formula developed for this study to estimate oxygen consumption capacity measured $\mathrm{VO}_{2}$ max levels of national teams participating in 2010 and 2014 FIFA World Cup as $60.52 \mathrm{ml} / \mathrm{kg} / \mathrm{min}$ and 56.50 $\mathrm{ml} / \mathrm{kg} / \mathrm{min}$, respectively. It can be argued that these values are lower than $\mathrm{VO}_{2}$ max values measured in recent years. It was also demonstrated that average running distances of national teams participating in 2010 and 2014 FIFA World Cup were nearly 9500 meters, which is lower than the running distances measure in recent years. Finally, no significance or correlation was observed between running distance and success in the tournament.

\section{References}

Aşçı, A. (2013). Futbolda Dayanıklılık Uygulamaları, 5th Training Science Congress, Hacettepe University, Faculty of Sport Sciences, Ankara.

Cooper, K. H. (1968). A means of assessing maximum oxygen intake. JAMVA, 203, 135-138.

Edwards, A. M., Clark, N., \& Macfadyen, A. M. (2003). Lactate and ventilatory thresholds reflect the training status of professional soccer players where maximum aerobic power is unchanged. Journal of Sports, Science \& Medicine, 2(1), 23-29.

Günay, M., \& Yüce, A. (1996). Futbol Antrenmanının Bilimsel Temelleri, Ankara.

İslegen, C. (1987). Değisik liglerde oynayan bölgesel profesyonel futbol takımlarının fiziksel ve fizyolojik profilleri. Turkish Journal of Sports Medicine, 22(2), 83-89.

Kızılet, A., Erdem, K., Karagözoglu, C., Topsakal, N., \& Çalıskan, E. (2004). Evaluation of some physical and physiological profiles of soccer players based on pitch position, Gazi Journal of Physical Education and Sport Sciences, 67.

Koc, H., Gökdemir, K., \& Kilınc, F. (2000). The effects of inter-season training on physical and physiological parameters on Kütahyaspor soccer team, Gazi Journal of Physical Education and Sport Sciences, 122-127.

Marangoz, İ., \& Gençay, Ö. A. (2017). The comparison of physical and physiological characteristics of Kahramanmaraşspor with professional football teams of Siirtspor at the competition season, The Journal of Academic Social Science, 5(56),374. https://doi.org/10.16992/ASOS.12801

McIntyre, M. C. (2005). A Comparison of the physiological profiles of elite Gaelic footballers, hurlers, and soccer players. British Journal of Sports Medicine, 39(7), 437-439. https://doi.org/10.1136/bjsm.2004.013631

Müniroğlu, S., Koz, M., Atıl, M., Erongun, D., \& Bulca, Y. S. (2000). A study on the examination of the physical and physiological properties of a football team in the Turkish Professional First Football League. Gazi Physical Education and Sports Science Congress, 1, 109-113.

Ostojić, S. M. (2000). Physical and physiological characteristics of elite Serbian soccer players. Facta universitatis-series: Physical Education and Sport, 1(7), 23-29.

Reeves, J. S., Poh, B., Brown, M., Tizzard, N., \& Ismail, M. (1999). Anthropometric measurements and body composition of English and Malaysian footballers. Malaysian Journal of Nutrition, 5(1), 79-86.

Reilly, T. (2003). Motion analysis and physiological demands. In: Reilly T, Williams AM, editors. Science and Soccer. London: Routledge, 2003, 59-72

Sınırkavak, G., Uğur, D., \& Çetinkaya, O. (2004). The relation between the body composition and maximal oxygen capacity in elite sportsmen, Cumhuriyet Medical Journal, 26, 171-176. 
Tahara, Y., Moji, K., Tsunawake, N., Fukuda, R., Nakayama, M., Nakagaichi, M., \& Aoyagi, K. (2006). Physique, body composition and maximum oxygen consumption of selected soccer players of Kunimi High School, Nagasaki, Japan. Journal of Physiological Anthropology, 25(4), 291-297. https://doi.org/10.2114/jpa2.25.291

Wahl, A. (2005). Ayaktopu: Futbolun Öyküsü, Translation: Cem İleri, İstanbul.

Yamaner, F. (1987). The measurement and evaluation of various physical capacities in Gençlerbirliği U-21 football team, Master Thesis, Gazi University, Ankara.

Yamaner, F. (1990). The analysis of the physiological characteristics of Galatasaray professional soccer team players and elite professional soccer players in other countries. Marmara University, Doctoral Dissertation, İstanbul.

\section{Copyrights}

Copyright for this article is retained by the author(s), with first publication rights granted to the journal.

This is an open-access article distributed under the terms and conditions of the Creative Commons Attribution license which permits unrestricted use, distribution, and reproduction in any medium, provided the original work is properly cited. 